\title{
Německá minulost českého pohraničí v historickém vědomí obyvatel Karlovarského kraje*
}

\author{
SANDRA KREISSLOVÁ** - VÁCLAV JAROŠ***
}

\author{
German Past Czech Borderland in the Historical Consciousness of the Population \\ of Karlovy Vary Region
}

\begin{abstract}
A contribution with a regional focus will concentrate its attention on the West Bohemian borderland, specifically the Karlovy Vary Region. For centuries, it was largely shaped by the German-speaking population. The authors will focus here on the question of historical consciousness of the Karlovy Vary Region current residents, when it comes to the German past of the region in which they live. Using a quantitative survey and visualisation by means of comparative mental maps of the Gould and Lynch type, they examine the views of and attitudes to selected historical milestones in Czech-German relations, historical consciousness of the existence of the German population and its effect in the region under study and, last but not least, the relationship to the current German ethnic minority.
\end{abstract}

Keywords: historical consciousness; collective memory; borderland; Czech-German relations; quantitative research; Karlovy Vary Region

DOI: $10.14712 / 23363525.2017 .39$

\section{Úvod}

Česko-německé vztahy se v posledních desetiletích staly jedním z předních témat humanitního a společenskovědního bádání. Na zpracování této látky se významně podílí především historiografie, která reflektuje jak období předcházející nucenému vysídlení německy hovořícího obyvatelstva, tak i poválečný vývoj a s ním spojené migrační vlny a transformaci pohraničí. ${ }^{1}$ Domácí sociologické a politologické výzkumy v rámci této problematiky sledují otázku názorů a postojů, které česká veřejnost zaujímá k pováleč-

* Článek vznikl za podpory grantového projektu na podporu excelence v základním výzkumu GAČR č. P410/12/ G113 s názvem Výzkumné centrum historické geografie - Historical Geography Research Centre, řešeného na Př́rodovědecké fakultě Univerzity Karlovy v letech 2012-2018.

** PhDr. Sandra Kreisslová, Ph.D., Katedra psychologie, Provozně ekonomická fakulta, Česká zemědělská univerzita v Praze, Kamýcká 129, 16521 Praha 6. E-mail: kreisslova@pef.czu.cz.

****Mgr. Ing. Václav Jaroš, Katedra sociální geografie a regionálního rozvoje, Přírodovědecká fakulta, Univerzita Karlova, Albertov 6, 12800 Praha 2. E-mail: vasekjaros@seznam.cz.

1 Již v roce 1990 byla založena Společná československo-německá komise historiků (po rozpadu federálního státu rozdělena na česko-německou a slovensko-německou sekci), zkoumající společné česko-německé a slovensko-německé dějiny především 20. století. Vedle aktivit této komise a bohaté literární produkce Ústavu pro soudobé dějiny AV ČR je nutné zmínit edici Vysídlení Němců a proměny českého pohraničí 1945-1951, dokumentující materiály o organizaci, průběhu a důsledcích migračních proudů probíhajících od roku 1945 do roku 1951 na území českých zemí se zvláštním zřetelem na nucené vysídlení a osidlování [Arburg - Staněk 2010a, 2010b, 2011]. Nejvýznamnějším autorem zabývajícím se postavením německy hovořícího obyvatelstva v poválečném období a v době socialismu zůstává Tomáš Staněk [např. 1991, 1993], z novějších prací je to pak např. monografie Matěje Spurného [2011] a Tomáše Dvořáka [2012]. 
nému „odsunu“ Němců a tzv. Benešovým dekretům. ${ }^{2}$ Pozornost sociologů je soustředěna též na nově vznikající česko-německé přeshraniční relace [např. Jerrábek 2012; Zich 2007a], formování lokálních identit [např. Houžvička - Novotný 2007; Zich - Roubal Spalová 2003] a německou menšinu. ${ }^{3}$ Etnologie se o tzv. novoosídlenecké pohraničí a život zdejšího obyvatelstva intenzivně zajímá již od padesátých let minulého století, vztahy Čechů a Němců jsou však v tomto předrevolučním období reflektovány spíše okrajově. V současné etnologické produkci zaujímá v tomto ohledu přední místo dílo Petra Lozoviuka, jehož badatelské aktivity se soustředí na každodennost a interetnické vztahy česko-saského pomezí [2012] a obecněji také na možnosti a perspektivy etnografického studia pohraničí [2009], a etnoložky Jany Noskové, zabývající se především vzpomínkovou kulturou českých Němců a různými aspekty jejich každodennosti [za všechny např. Nosková - Čermáková 2013].

Rovněž předkládanou studii lze považovat za příspěvek k výzkumu vztahů mezi Čechy a Němci na území českých zemí. V tomto smyslu se naše badatelské úsilí soustředí na otázku historického vědomí obyvatel českého pohraničí o německé minulosti regionu, ve kterém žijí. V intencích tohoto tázání sledujeme prostřednictvím kvantitativně orientovaného výzkumu názory a postoje k vybraným historickým mezníkům vzájemných česko-německých relací, historické povědomí o existenci německého obyvatelstva a jeho vazeb na území, které před rokem 1945 obývali, a v neposlední řadě vnímání současné německé menšiny. ${ }^{4}$ Konstruované obrazy o německé minulosti, jež se nacházejí „v hlavách“ zdejších obyvatel, jsme se následně snažili uchopit také prostřednictvím mentálních map. Takto jsme mohli graficky znázornit subjektivní percepci geografického prostoru, jež je ovlivněna př́mou zkušeností dotazovaných jedinců, kolektivní pamětí a celkovou imagí dané lokality.

Regionálně byl výzkum zasazen do Karlovarského kraje, který po staletí formovalo převážně německy hovořící obyvatelstvo a kde je dodnes patrný jeho vliv. Pozůstatky německé kultury se projevují ve specifické architektuře, krajinném rázu či sídelní struktuře. Všechny tyto aspekty v sobě odráží činnost tohoto společenství a jeho působení v krajině, které přerušilo nucené vysídlení po druhé světové válce, na jehož základech se následně budovala nová poválečná společnost v pohraničí. Výběr daného regionu souvisí také se skutečností, že v této oblasti žije v současné době nejvyšší podíl obyvatelstva hlásícího se k německé národnosti ${ }^{5}$ a je také jediným krajem v České republice, jehož celé území spadalo do tzv.

2 Sociologické uchopení fenoménu pohraničí předkládá badatelský tým Sociologického ústavu AV ČR. Srov. např. Houžvička [2005]. Centrum pro výzkum veřejného mínění Sociologického ústavu AV ČR pak pravidelně informuje o stavu veřejného mínění k otázce „odsunu“ a „Benešových dekretů“ a příhraniční spolupráce.

3 V devadesátých letech byl realizován sociologický výzkum Čeští Němci nebo němečtí Češi? Prostřednictvím biografických vyprávění Němců, kteří po roce 1946 zůstali v tehdejším Československu, mapoval vývoj česko-německých vztahů a snažil se zachytit problematiku identity českých Němců. Výsledky z tohoto výzkumu jeho autoři publikovali v rámci časopisu Biograf. Nejnověji k německé menšině v České republice pak Kreisslová, Novotný [2015].

4 Z hlediska širšího pojetí historického vědomí nechápeme tento pojem pouze jako prostý souhrn historických znalostí, nýbrž obecněji jako individuální a kolektivní porozumění minulosti a schopnost propojení tohoto vědění o minulosti s prrítomností a budoucností [blíže k tomu Šubrt - Vinopal 2012; Šubrt 2010].

5 Dle pravidelného sčítání obyvatelstva zjištujeme, že počet občanů, kteří se oficiálně hlásí k německé národnosti, zaznamenává výrazný a trvalý pokles. V roce 1991 se k této národnosti přihlásilo 47789 občanů. Předpokládá se však, že tento údaj byl značně poddimenzován, jelikož se mnozí Němci z důvodů špatných zkušeností z minulosti k německé národnosti nepřihlásili. V roce 2001 se jednalo o 39106 občanů a v rámci posledního sčítání lidu v roce 2011 se k německé národnosti přihlásilo už jen 18658 osob. Nejvíce obyvatel německé 
Sudet připojených v roce 1938 k Německé ríši. Zájmového území se tak výrazně dotkly veškeré historické události, které ovlivnily vývoj česko-německých vztahů.

Sledovaná oblast je také vzhledem k působení německé menšiny do značné míry specifická, nebot’ se jednalo o jedno z mála míst bývalého Československa, kde mohli obyvatelé německé národnosti provozovat svou organizovanou činnost, zejména pak od vzniku Kulturního sdružení občanů ČSSR německé národnosti v roce 1968 [Staněk 1993]. Po roce 1989 zde vzniklo několik dalších nových svazů a spolků, které dnes spadají pod Shromáždění německých spolků $v$ České republice a působí zde společně s předrevolučním Kulturním sdružením, které od roku 2014 funguje pod názvem Spolek Němců a přátel nèmecké kultury. ${ }^{6}$ Přestože je zde německá menšina zastoupena kompaktněji nežli v jiných částech republiky, potýká se se stejnými problémy jako jinde; nepř́znivá věková struktura, vysoká míra asimilace s majoritním obyvatelstvem a absence mládeže představují jednu z hlavních výzev budoucího směřování této skupiny. Ze zmíněných organizací, jejichž činnost je obecně $z$ velké části archaicky laděná, několik místních skupin vystupuje velmi aktivně a jsou zřejmě nejlepším př́kladem kulturní revitalizace německých folklorních tradic v České republice [Kreisslová - Novotný 2015: 107-110]. Obyvatelé regionu tak mohou prostřednictvím těchto aktivit přicházet se zástupci německé menšiny do kontaktu, seznamovat se s lokálním německým nářečím, kulturou a historií.

\section{Kolektivní pamět a identita v pohraničí: zapomenuté a znovuobjevené „Sudety“}

Koncept kolektivní paměti (mémoire collective) byl poprvé vymezen již v meziválečném období francouzským sociologem Mauricem Halbwachsem [1994 (1925)]. Dle jeho sociálně konstruktivistického pojetí paměti se vzpomínky utváři až díky sociálním interakcím a komunikaci mezi jedinci. Jak individuální, tak kolektivní vzpomínání se tak dle autora odehrává $\mathrm{v}$ rámci tzv. sociálních rámců (cadres sociaux), v nichž je udáváno, jaké obrazy o minulosti jsou pro prŕtomnou existenci a identitu sociální skupiny podstatné a hodné zapamatování. Jedná se o dynamický proces, během něhož musí být minulost svými nositeli neustále komunikována a re-konstruována, což se děje vždy ve vztahu k př́ítomnosti a ve prospěch těch, kteř́ se na jejím uchování podílejí. To, co komunikováno není, tak upadá v zapomnění, z čehož vyplývá selektivní charakter paměti.7

národnosti je pak situováno v Karlovarském kraji, kde se k této národnosti přihlásilo 4504 osob, což je přibližně $1,5 \%$ z celkového počtu 310245 obyvatel. Tento údaj však vedle výše uvedeného důvodu není zcela věrohodný také proto, že při sčítání lidu vyplnilo svou národnost pouze $60 \%$ obyvatel [ČSÚ, Sčítání lidu, domů a byti̊].

6 Ke spojení obou hlavních představitelů německé menšiny z různých důvodů nikdy nedošlo. Starší Spolek Němců v současné době čía 20 místních skupin, přičemž v Karlovarském kraji se nacházejí čtyři z nich (Skalná, Kraslice, Sokolov, Pernink). Pod Shromáždění německých spolků se hlásí 22 samostatně registrovaných svazů a 15 tzv. setkávacích středisek. Ve sledované oblasti se nachází dva z těchto svazů - Chebské společenství při Horním Slavkově a Svaz Němců - region Chebsko, který disponuje šesti místními skupinami (Sokolov, Skalná, Karlovy Vary, Nejdek, Cheb, Nečtiny - Preitenstein). V Chebu je také umístěno česko-německé setkávací středisko Begegnungszentrum Balthasar-Neumann-Haus [Kreisslová - Novotný 2015: 51-60].

7 Již samotné vzpomínky jedinců se $\mathrm{z}$ různých důvodů mohou v mnohém lišit od skutečně prožité minulosti. Roli zde hraje např. zapomínání, zjednodušování či dotváření vzpomínek. Další příčina zkreslování vzpomínek vyplývá z propojení paměti a identity, nebot lidé mají sklon vidět sebe sama a skupinu „my“ v lepším světle [blíže k tomu srov. Welzer 2008: 32-34]. 
Vzpomínky na minulost jsou generačně předávány prostřednictvím komunikativní a kulturní formy kolektivní paměti. ${ }^{8}$ Znovu a znovu jsou připomínány události a zkušenosti, které považuje určitá sociální skupina za důležité. $V$ našem případě se jedná o historicky významné okamžiky určitého regionu a praktické zkušenosti jeho obyvatel plynoucí $\mathrm{z}$ každodenního života $\mathrm{v}$ něm. Uchovávány a předávány jsou tak společné hodnoty, kulturní návyky a zkušenosti předků vážící se přímo k životu v daném místě a tím je utvářena regionální identita zdejšího obyvatelstva.

Proces konstrukce regionální identity a potažmo také identity regionu ${ }^{9}$ popsala ve své teorii (Identity process theory) britská sociální psycholožka Glynis Breakwell. Dle Breakwell se jedná o dynamický produkt vzájemného působení na jedné straně vědomí, paměti a vnímání okolí a na straně druhé fyzických a sociálních struktur a procesů tvořících sociální kontext. Takto definovanou identitu staví na čtyřech principech, z nichž klíčový je princip vědomí příslušnosti k určitému území a současně vymezení se vůči jiným regionům a jejich obyvatelům (distinctiveness principle). Další principy tvoří uvědomění si kontinuity vlastního života na daném území (continuity principle) a princip sebeúcty (self-esteem principle), tedy pocit hrdosti na svou identitu a region. A konečně je to princip sebeúčinnosti (self-efficacy principle), jež lze chápat jako zpř́ijemnění a zjednodušení každodenního života, pramenící z př́slušnosti k danému území [Breakwell 1993: 205-206].

Utváření regionální identity je dlouhodobý proces spojený s každodenní zkušeností se životem v regionu. Kontinuita života na daném území se zdá být proto stěžejní. Při studiu Karlovarského kraje - ostatně jako i v jiných částech českého, moravského a slezského pohraničí - však narážíme na problém narušení kontinuálního vývoje osídlení „odsunem“/,vyhnáním“ někdejších německých obyvatel. Nové obyvatelstvo, které do pohraničí přicházelo z českého vnitrozemí a různých oblastí střední a východní Evropy, si s sebou přinášelo různorodé kulturní, náboženské a jazykové zvyklosti a přinejmenším ve svých počátcích velmi obtížně hledalo cestu k formování společné identity pohraničí. Chyběla sounáležitost s „druhými“, stejně jako hlubší vztah ke zdejší krajině, která se měla stát jejich novým domovem. Navázat na kulturní dědictví, jež zde bylo zanecháno, nebylo v poválečné protiněmecké atmosféře žádané, vše „německé“ podléhalo silné stigmatizaci. Příchozí obyvatelstvo nemělo možnost převzít zkušenosti od svých německých předchůdců a kolektivní identita a pamět v tomto regionu se musela začít utvářet nově. Znovu se musely začít budovat symboly a hodnoty, se kterými by se mohli noví osídlenci a následně i jejich potomci ztotožnit. ${ }^{10}$ Tento proces byl od svého počátku ovlivněn kolektivním trau-

8 Podle Aleidy a Jana Assmannových [2001: 46-53, 2006: 31-36] lze rozlišit komunikativní a kulturní formu kolektivní paměti. Zatímco komunikativně předávaná minulost je vázána na žitou historickou zkušenost svých nositelů a jedná se tudíž o vzpomínky na nedávnou minulost, pamět kulturní přesahuje generační vzpomínání a směřuje až k mýtickým počátkům. Jejím úkolem je transgenerační přenos vzpomínek prostřednictvím vnějších médií, jako jsou texty, obrazy, monumenty či obřady. K různým teoretickým konceptům paměti dále srov. Erll [2005] nebo Maslowski - Šubrt [2015].

9 Zatímco regionální identitu zde chápeme jako specifický druh kolektivní identity obyvatel ve vztahu $\mathrm{k}$ jejich území, $\mathrm{v}$ př́ípadě image regionu se jedná o obraz regionu, který se utvárí jak v myslích samotných obyvatel daného území, tak u lidí žijících mimo něj. Tito lidé nemuseli region nikdy navštívit, představu o něm si mohli vytvořit na základě informací „z druhé ruky“. Identitu regionu (image) tedy rozlišujeme na vnitřní a vnější [srov. Paasi 1986: 105-146; Chromý - Janů 2003: 105-117].

10 Dle finského geografa Anssi Paasiho [1986: 105-146] se regionální identita vytváří souběžně s jednolitými fázemi tzv. institucionalizace regionu, tj. dynamického procesu vzniku, existence, změny a obnovy nebo zániku regionu. V první fázi tohoto procesu se vytváří územní tvar regionu, dochází k ustálení hranic a budování 
matem obětí11 ${ }^{1}$, prostřednictvím kterého se Němcům přisuzovala kolektivní vina za „Mnichov“, okupaci a hrůzy druhé světové války, a posléze byl zasažen ideologickým omezením a řízenou tabuizací poválečného „odsunu“ Němců ze strany komunistického režimu. ${ }^{12}$

Kolektivní pamět a historické vědomí části české společnosti je tak dodnes zatížena mnohými stereotypy a resentimenty, $\mathrm{k}$ čemuž přispívají i někteří představitelé politické reprezentace, kteří toto téma využívají $\mathrm{k}$ manipulaci s veřejným míněním, a dále částečně také média, jež mnohdy redukují česko-německé vztahy na „sudetoněmeckou otázku“ a požadavky funkcionářů Sudetoněmeckého krajanského sdružení [Šmídová 1998: 273]. Na druhé straně se prostor tzv. Sudet po roce 1989 postupně stal dějištěm různých občanských iniciativ, které se snaží německou minulost opět „znovuobjevit“ a „zpřítomnit“ formou výstav, besed a seminářu či prostřednictvím utváření různých míst paměti ${ }^{13}$, např́iklad v podobě pamětních desek, památníků či muzeí. ${ }^{14}$ Cílem těchto aktivit je senzibilizovat současnou českou společnost pro historii společného soužití Čechů a Němců na území českých zemí. V tomto ohledu nejvíce rezonují připomínky poválečných excesů během tzv. divokých odsunů ${ }^{15}$, jež narušují schematické kategorizování Němců coby pachatelů a z části z nich činí oběti mezietnického násilí. Vůči těmto aktivitám se ostře vyhraňují především představitelé Klubu českého pohraničí a Vlasteneckého sdružení antifašistů. Názorově rozdělují také českou společnost, což lze dobře sledovat právě v těch oblastech,

regionálního povědomí obyvatel. V dalši fázi se ukotvují územní symboly, které region charakterizují a zároveň odlišují od ostatních. Vzniká tak symbolický tvar regionu, který tvoří v první řadě název území a dále přírodní a sociokulturní symboly. Konkrétním př́kladem mohou být značky místních produktů. Během třetí fáze se utváří institucionální tvar regionu (vznik politických, administrativních, ekonomických, vzdělávacích a jiných institucí). A konečně za čtvrté dochází k ustanovení regionu jako části regionálního systému a regionálního povědomí obyvatel uvnitř i vně regionu. Optikou Paasiho konceptu lze říci, že v případě Karlovarského kraje došlo po roce 1945 k nevratným změnám a k zániku regionu. Zároveň se zánikem se ovšem v rámci poválečného osidlování opět započaly jednotlivé fáze institucionalizace nového regionu, který se tak znovu stal součástí kontingentního procesu reprodukce a transformace společnosti.

11 Kolektivní/kulturní trauma přesahuje individuální rovinu traumatu a zasahuje určitou skupinu, jejíž integrita a stabilita byla narušena katastrofickou událostí. Toto trauma je diskursivně konstruované svými nositeli mluvčími a představiteli identity a kultury, na nichž závisí, zda se určitá událost stane kolektivně sdíleným traumatem. Kolektivní trauma lze přisoudit jak obětím, tak viníkům šokující události [Alexander - Eyerman 2004; Giesen 2002; Tomášek 2015: 179-194].

12 Komunistická propaganda vytvářela dvojí obraz Němců; zatímco se Československo společně s Německou demokratickou republikou stalo součástí sovětského bloku a východní Němci byli chápáni jako bratři, západní Němci vystupovali v podobě západních imperialistů a byli spojováni se sudetoněmeckým revanšismem. Český mýtus o Němcích jakožto „dědičných nepřátelích“ se však formoval již v období národněobrozeneckého hnutí na počátku 19. století a jeho kořeny sahají až do středověku [srov. Rak 1994].

13 Tzv. místa paměti (les lieux de mémoire) lze považovat za médium kulturní paměti. Jedná se o koncept francouzského historika Pierra Nory [1984], který pod tímto metaforickým označením chápe místa, v nichž krystalizuje pamět a manifestuje se, tak aby neupadla $\mathrm{v}$ zapomnění. V této studii vycházíme $\mathrm{z}$ širšího pojetí tohoto pojmu.

14 Zřejmě nejaktivněji na tomto poli působí občanská iniciativa Antikomplex, která již na konci devadesátých let pro veřejnost otevřela téma nuceného vysídlení Němců a proměny krajiny „Sudet“ prostřednictvím putovní fotografické výstavy Zmizelé Sudety [2004]. Jednou z posledních viditelných akcí se dále stala Pout' smírení, jejímž cílem je připomenout události spojené s koncem druhé světové války a osudy německy hovořících Brňanů, kterých se dotkl tzv. brněnský pochod smrti. Devátý ročník této pietní akce, který se uskutečnil k 70. výročí skončení druhé světové války, vyvolal také silné politické reakce. Několik dní před samotným vzpomínkovým pochodem brněnští zastupitelé schválili Deklaraci smírení a společné budoucnosti, čímž vyjádřili lítost nad tehdejšími událostmi [srov. Kreisslová 2016: 284-295].

15 Vedle tzv. brněnského pochodu smrti došlo k rozsáhlým protiněmeckým akcím např. v Postoloprtech, v Ústí nad Labem nebo Chomutově. Ve sledované oblasti proběhly poválečné masakry Němců v Tocově nebo Doupově. K problematice tzv. divokých odsunů srov. Arburg, Staněk [2010b], Staněk [2005, 1996]. 
kde k tragickým událostem došlo a místní obyvatelé zde vedou vášnivé diskuse o tom, zda mají být tato místa a události připomínány, či zapomenuty. Pole kulturní paměti „Sudet“ se tak v posledních desetiletích stalo prostorem sporu o různou interpretaci dějin [srov. Kreisslová 2016: 284-295]. ${ }^{16}$ Důvodů těchto odlišných pohledů a představ o minulosti může být celá řada: odlišně prožitá a předávaná historická zkušenost, generační zasazení, vzdělání, etnický původ či politická orientace. V neposlední řadě se na chápání a interpretaci historických událostí spolupodílí také školní výuka, historiografie, média a další [Šubrt, Pfeiferová 2010: 22].

\section{Historické vědomí o německé minulosti Karlovarska v paměti místního obyvatelstva}

Dotazníkové šetření, které jsme provedli na přelomu let 2012/2013, bylo pokusem alespoň o částečné nahlédnutí do historického vědomí o německé minulosti českého pohraničí u současných obyvatel Karlovarského kraje. ${ }^{17}$ Započněme toto tázání otázkami zjištujícími původ samotných dotazovaných. Zajímalo nás, zda rodiny respondentů ve sledované oblasti žily již před druhou světovou válkou, nebo do českého pohraničí přišly po roce 1945. Předpokládali jsme přitom, že odpovědi respondentů se vedle věku a vzdělání mohou lišit i právě $\mathrm{v}$ závislosti na délce usídlení $\mathrm{v}$ pohraničí. Uved’me tedy nejdřive, že $\mathrm{z}$ celkového počtu 232 účastníků výzkumného šetření pocházelo $43 \% \mathrm{z}$ rodin poválečných novoosídlenců. Celých $41 \%$ dotazovaných lze považovat za tzv. starousedlíky, tedy obyvatele, jejichž alespoň jeden $\mathrm{z}$ předků $\mathrm{v}$ regionu žil již před druhou světovou válkou. Mezi nimi převažovaly osoby mající český původ (39 osob), 15 osob bylo s německým obyvatelstvem spojeno př́ibuzenským vztahem, smíšený česko-německý původ uvedlo 24 respondentů. Poměrně velká část dotazovaných (16 \%) neměla o svém původu a př́íchodu do pohraničí žádné informace.

Dále jsme také zjištovali, zda mají účastníci výzkumu povědomí o historii domu, ve kterém žijí. $V$ necelé polovině př́ípadů (47 \%) žijí dotazovaní v domech postavených před druhou světovou válkou. $Z$ těchto $47 \%$ byly přibližně $2 / 3$ obývány Němci a zhruba z $14 \%$ Čechy, téměř pětina respondentů pak nemá o původních majitelích domu žádné zprávy. $45 \%$ dotazovaných žije v domech postavených po roce $1945.8 \% \mathrm{z}$ celkového počtu respondentů není s historií svého bydliště obeznámeno vůbec.

Otázky po původu domu, který dotazovaní obývají, nás přivedly ke zkoumání postojů a názorů k poválečnému nucenému vysídlení německy hovořících obyvatel. V souvislosti s dotazem, zda byl dle respondentů poválečný „odsun“ spravedlivý, lze aktéry výzkumného šetř̌ení rozdělit na přibližně tři stejné části. Největší skupinu tvořili zastánci „odsunu“ jako spravedlivého řešení poválečné situace (37\%). Jen o osm respondentů méně zastává

16 Spory o vznik a podobu pietního místa připomínající poválečné násilí na Němcích proběhly např. v Ústí nad Labem, Teplicích nad Metují nebo při budování pomníku u Dobronína na Jihlavsku.

17 Dotazníkového šetření se účastnilo celkem 232 respondentů, z toho 58 \% žen a $42 \%$ mužů. Průměr v rámci věkové struktury činil 39 let a nejvíce dotazovaných uvedlo jako nejvyšší dosažené vzdělání středoškolské s maturitou (39,22 \%) a vysokoškolské (28,02 \%). Sběr dat probíhal ve všech sedmi správních obvodech s rozšířenou působností Karlovarského kraje, z celkového počtu 132 obcí bylo zastoupeno 59, přičemž nejvíce respondentů pocházelo z Karlových Varů (24,57 \%) a jejich blízkého okolí (10,57 \%), Sokolova (6,03 \%) a Chebu $(5,17 \%)$ čili největších sídelních útvarů v regionu. Takto získaná primární data byla následně digitalizována a zpracována ve statistickém softwaru SPSS. Prostorová data byla vektorizována za pomoci softwaru ArcGIS. Data ve vektorové podobě se posléze stala základem pro prostorové analýzy a kartografická srovnávání. 
opačný názor a považují „odsun“ za nespravedlivý (33\%). Necelých 30 \% dotazovaných pak nemá na tuto problematiku jasně vyhraněný názor a nepřiklání se proto ani $\mathrm{k}$ jedné z nabízených možností odpovědi.

S problematikou „odsunu“/„vyhnání“ úzce souvisí otázky kolem tzv. Benešových dekretů. Toto zavádějící označení se v České republice vžilo pro část dekretů prezidenta republiky, které po druhé světové válce regulovaly postavení Němců, Mad’arů a dalšího „nepřátelského obyvatelstva“ v tehdejším Československu. Diskuse o jejich zrušení a navrácení majetku sudetským Němcům již dlouhodobě zatěžují česko-německé vztahy [srov. Blaive - Mink 2003]. Jedním z prvních kroků vedoucích ke zlepšení vzájemných relací byla bilaterální Smlouva mezi tehdejší ČSFR a SRN o dobrém sousedství a přátelské spolupráci z roku 1992. Druhým základním dokumentem se stala česko-německá deklarace z roku 1997, jejímž záměrem bylo ukončit vleklé spory z minulosti a soustředit se na společnou kooperaci v budoucnosti. Téma „Benešových dekretů“ se však v různých etapách znovu objevovalo především v souvislosti s výroky různých politických představitelů ve snaze ovlivnit veřejné mínění jak na německé/rakouské, tak české straně. ${ }^{18}$ Vztah veřejnosti k této otázce v České republice dlouhodobě sleduje Centrum pro výzkum veřejného mínění Sociologického ústavu $A V \check{C} R$. Výsledky těchto empirických šetření nám ukazují trvalou převahu osob, jež se k zachování dekretů přiklání. Postupně však dochází k jejich pozvolnému snižování a naopak mírnému navyšování jejich odpůrců a také těch, kteří danou problematiku nedokáží posoudit. ${ }^{19}$

Rovněž v rámci našeho výzkumného šetření jsme sledovali názory respondentů na platnost či neplatnost dekretů. Celých $35 \%$ dotazovaných lze považovat za zastánce těchto zákonů, tyto osoby se vyjádřily zásadně proti jakémukoliv navracení majetku potomkům původních německých majitelů. Umírněnější tábor tvořili ti, kteří se vyjádřili pro přezkoumání dekretů a v některých př́padech by majetek vrátili (32 \%). Jednoznačný názor na tuto problematiku nemá $21 \%$ dotazovaných a pouhých $8 \%$ dotazovaných se vyslovilo pro úplné zrušení dekretů. Do jaké míry mohly být odpovědi ovlivněny předvolební kampaní během prvních prímých voleb prezidenta republiky, která probíhala ve stejné době jako dotazníkové šetření, je otázkou. Z celorepublikových šetření však vyplývá, že stávající trend pozvolného snižování zastánců dekretů tato diskuse významněji neovlivnila.

$\mathrm{V}$ našem výzkumu jsme rovněž sledovali, zda ve skupině dotazovaných, kteří žijí v domech po původních německých majitelích, převažují podporovatelé dekretů oproti respondentům, kteři vlastní dům postavený až po roce 1945. Tento předpoklad se ovšem nepotvrdil. Postoje respondentů obývajících domy postavené před druhou světovou

18 Významný přelom v česko-sudetoněmeckých vztazích nastal v roce 2015, když se Sudetoněmecké krajanské sdružení rozhodlo vypustit ze svých stanov „majetkové nároky“ na Českou republiku a „právo na návrat do vlasti“, což mnoho českých politiků uvítalo.

19 Až do roku 2005 se k zachování platnosti prezidentských dekretů opakovaně přikláněly zhruba dvě třetiny respondentů (2002 - 67 \%, $2004-66 \%, 2005$ - 64 \%), počet těch, kteří se klonili k jejich zrušení, se měnil jen pozvolna $(2002-5 \%, 2004-8 \%, 2005-7 \%)$. Nárůst negativních postojů české veřejnosti $\mathrm{k}$ jejich zrušení lze mimo jiné přisoudit tehdy probíhajícím př́stupovým jednáním České republiky do Evropské unie, během nichž se debata kolem dekretů velmi vyostřila [srov. Domnitz 2007]. Mezi lety 2006 až 2013 se počet osob, které se vyjadřovaly pro zachování dekretů, postupně snižoval (2006 - 53 \%, $2007-52 \%, 2009-65 \%, 2011-49 \%$, $2013-50$ \%) a stoupal počet jejich odpưrců (2006 - 13\%, $2007-11 \%, 2009-8 \%, 2011-17 \%, 2013-14 \%$ ). Odlišný byl v tomto ohledu rok 2009, kdy se téma „Benešových dekretü“ znovu objevilo v souvislosti s ratifikací Lisabonské smlouvy a průzkumy prokázaly návrat $k$ dřivěǰím postojům. Uvedená data byla převzata $\mathrm{z}$ výzkumného šetření Centra pro výzkum veřejného minèní Sociologického ústavu $A V$ ČR. 
válkou i po ní byly přibližně stejné. Znatelné rozdíly se však objevily u samotné skupiny respondentů obývající domy postavené před druhou světovou válkou. Zde se ukázalo, že osoby žijící v domech dřive obývaných Němci se více staví za zachování dekretů (46,9 \%) nežli lidé obývající domy po českém obyvatelstvu $(7,1 \%)$.

V př́padě obou výše řešených otázek (spravedlnost „odsunu“ a platnost „Benešových dekretư“) mohli respondenti svou odpověd” písemně rozvést. Tuto možnost nejčastěji využívaly osoby ospravedlňující nucené vysídlení a konfiskaci majetku. Zde se opakovaně objevoval názor, že „odsun“ sice nebyl zcela spravedlivý, dnes však majetek už vracet nelze. Frekventovaný byl také princip „tlusté čáry za minulostí. Komentár, který by nucené vysídlení zcela odsuzoval, jsme nezaznamenali.

Povědomí o německé historii jsme dále zjištovali prostřednictvím otázky zaměřené na znalost původního německého názvu obce, v níž dotazované osoby žijí. Ukázalo se, že přibližně $2 / 3$ respondentů německý název své obce znají, a to př̀evážně v těch př́ípadech, kdy se jednalo o dostatečně známá a běžně používaná pojmenování. Za taková místa lze považovat velká města (Karlovy Vary/Karlsbad, Sokolov/Falkenau) ${ }^{20}$ a obce s čilým zahraničním cestovním ruchem (Františkovy Lázně/Franzensbad, Mariánské Lázně/ Marienbad). Dále sídla v bezprostř̌ední blízkosti státní hranice (Aš/Asch, Luby/Schönbach, Plesná/Fleißen) nebo historicky významné obce (Jáchymov/Sankt Joachimsthal, Skalná/ Wildstein, Kynšperk nad Ohř́/Königsberg). Určitou roli mohla sehrávat také podobnost některých českých a německých názvů jako $\mathrm{v}$ př́padě Aše, Jáchymova a názvů lázeňských měst. U některých obcí se ještě několik let po válce užival český ekvivalent původních německých názvů, což mohlo rovněž přispět $\mathrm{k}$ jejich hlubšímu zakořenění v paměti místních obyvatel (např. Sokolov - do roku 1948 Falknov nad Ohří, Skalná - do roku 1950 Vildštejn $\left.{ }^{21}\right)$.

Poněkud překvapivě působí výsledky respondentů pocházejících z Chebu, který lze zařadit do většiny výše zmíněných kategorií. Přestože německé označení Eger je všeobecně známé a zároveň se používá i pro název řeky Ohře, znala ho pouze polovina z 12 dotazovaných. Celkově se neznalost německého názvu obce projevila zejména u mladších respondentů. Více než $2 / 3$ dotazovaných, kteří na danou otázku odpověděli záporně, byli mladší 40 let. Naopak u osob, které touto znalostí disponovaly, byla hodnota 40 let mediánem.

Nejsou to pouze místopisné názvy, které připomínají německou minulost sledovaného kraje. Mnohem intenzivněji ve své každodennosti na místní obyvatele působí světově proslulé podniky a značky, jež jsou s tímto regionem neodmyslitelně spjaty a významně působí při utváření jeho symbolického tvaru jako součásti institucionalizace regionu. Vybrané společnosti byly založeny před druhou světovou válkou a vyvstává tak otázka, zda dotazovaní vědí o jejich předválečném vzniku a propojení s německy hovořícím obyvatelstvem. Ptali jsme se proto, zda je považují za historicky české nebo německé. Mezi podniky a značkami, které dotazovaní pokládali nejčastěji za české, se objevovala Korunní $(87,2 \%)$ a Karlovarské minerální vody $(85,9 \%)$ čili především firmy, jejichž názvy jsou dnes českojazyčné. Taktéž o Becherovce soudilo celých 78 \% respondentů, že je českého původu. Značku Mattoni označilo 55,1 \% osob za českou, 29,1 \% ji však nepovažovalo ani

\footnotetext{
20 Při uvedení německého názvu obce nebyl kladen důraz na pravopisnou správnost názvu. V případě Karlových Varů se často objevoval výraz Carlsbad, v případě Sokolova se několikrát objevil název Falknov. V obou případech byly odpovědi uznány jako správné.

21 Stejný název také nese hrad Vildštejn ve Skalné.
} 
za historicky českou, ani německou. U společností, které si ponechaly tradiční názvy jako Thun nebo Moser, se procento dotazovaných považujících společnosti za české snižoval (Thun 38,3 \%, Moser 52,4 \%) a navýšil se počet těch, kteří je označili za původně německé (Thun 40,1 \%, Moser 40,1 \%). V případě Becherovky a Korunní se rozdíl v odpovědích projevil v závislosti na věku respondentů, především mladší dotazovaní se domnívali, že se jedná o historicky české podniky. U ostatních společností se však tato vazba neprokázala a výsledky napříč jednotlivými věkovými skupinami si byly podobné. Rozdíly lze tedy přičíst přirozené variabilitě dat.

$\mathrm{V}$ neposlední řadě nás také zajímalo, jaké představy mezi aktéry výzkumu panují o podílu Němců na obyvatelstvu v jejich obci v předválečném období. Ve všech obcích dnešního Karlovarského kraje německy hovořící obyvatelstvo před druhou světovou válkou převažovalo, v mnoha obcích Češi nežili vůbec. V národnostně smíšených obcích dosahoval podíl Čechů většinou do $5 \%$, u velkých měst to bylo okolo $10 \%$. Největší část tvořili Češi na jihovýchodě kraje, kde v některých př́padech přesahovali i $1 / 3$ obyvatel [Statistický lexikon obcí v republice československé 1934]. Představy respondentů o podílu Němců na obyvatelstvu se však od reality významně lišily. Respondenti uváděli od jednoho do $100 \%$, přičemž v průměru se odpovědi pohybovaly okolo $60 \%$. Nejvyšší počet německy hovořících obyvatel byl přisuzován obcím Křižovatka, Kynšperk nad Ohří, Prameny, Lázně Kynžvart a Hájek, které byly dle mínění respondentů z více než 97 \% tvořeny Němci. Naopak v průměru nejmenší podíly uváděli obyvatelé obcí Hazlov, Krásný Les a Děpoltovice. Obecně přitom platilo, že extrémně nízkých, nebo naopak extrémně vysokých hodnot dosahovaly zejména obce s nízkým zastoupením počtu respondentů. U nejvýznamnějších sídel Karlovarského kraje (Karlovy Vary, Cheb, Sokolov, Ostrov, Aš) se dle odpovědí respondentů podíly Němců na obyvatelstvu pohybovaly přibližně okolo $50 \%$. Z těchto obcí zároveň pocházelo nejvíce dotazovaných a docházelo tak ke „zprůměrování extrémních" odpovědí.

Co se týká představ o absolutním počtu Němců v českých zemích v předválečném období, po jejich poválečném nuceném vysídlení a v současnosti, ukázala se jasná tendence početnost tohoto etnika $\mathrm{v}$ prvním ze zmíněných období podhodnocovat. ${ }^{22} \mathrm{~V}$ průměru byly uváděny hodnoty okolo 1,9 milionu, což je přibližně $60 \%$ reálné hodnoty. Zatímco představy o počtu Němců před rokem $1945 \mathrm{v}$ průměru podhodnocují reálnou hodnotou, počty příslušníků této menšiny po nuceném vysídlení a dnes jsou naopak poněkud nadsazené. Po poválečném vysídlení zůstalo dle respondentů v tehdejším Československu přibližně 350000 Němců (minimum - 200 / maximum - 2,3 milionu). Průměrný uváděný počet osob přináležejících k současné německé menšině se pohyboval okolo 290000 osob (minimum - 100 / maximum - 3 mil.). Více než 1/3 všech respondentů se pak domnívá, že dnes žije v České republice více Němců než bezprostředně po nuceném vysídlení, což může souviset s prríchodem tzv. nových Němců, tedy Němců z Německa, kteří se v České republice od roku $1989 \mathrm{z}$ různých důvodů usazují.

Při porovnání odpovědí respondentů dle dosaženého vzdělání se prokázal nejsilnější korelační vztah s reálnými hodnotami v př́padě respondentů se základním vzděláním.

22 V rámci sčítání lidu v roce 1930 se k německé menšině v rámci Československa přihlásilo celkem 3149820 osob [Statistickýlexikon obcí v republice československé 1934]. Při prvním poválečném cenzu v roce 1950 bylo zaznamenáno 159938 osob hlásících se k německé národnosti. A zopakujme, že v roce 2001 se tento počet snížil na 39106 občanů [ČSÚ, Sčítání lidu, domů a bytů]. 
Názory této skupiny se tak nejvíce blížily realitě, což přisuzujeme skutečnosti, že tento okruh respondentů byl tvořen spíše staršími osobami. To potvrdilo rovněž porovnání odpovědí dle jednotlivých věkových skupin. Nejrealističtější odhady v tomto ohledu vykazovali respondenti starší 60 let, naopak nejvíce se od statistických dat odchylovaly odpovědi dotazovaných mladších 20 let.

Dotazovaní měli také odpovědět na otázku, od kterého století se dle jejich názoru začalo německy hovořící obyvatelstvo v pohraničí českých zemí usazovat. V 53 př́padech respondenti uvedli století osmnácté, což byla nejčastěji udávaná odpověd. Naproti tomu průměrnou a mediánovou odpovědí se stalo 16., respektive 17 . století. Uváděným minimem bylo 8 . století a maximem 20. století, rozptyl odpovědí tak činil 12 století. Správnou odpověd', tedy 12. nebo 13 . století, uvedlo 33 respondentů, což představuje $14,22 \%$ všech odpovědí. Lze tedy konstatovat, že mínění dotazovaných se také v této otázce od historické reality výrazně lišilo.

\section{Prostorová percepce německého osídlení Karlovarského kraje}

Jedním ze stěžejních cílů výzkumného šetření bylo detailní zmapování prostorového vnímání Karlovarska s přihlédnutím k jeho německému osídlení. Pro tyto účely jsme do dotazníku zapracovali otázky sledující povědomí obyvatel o prostorových aspektech jevů souvisejících s životem německy hovořících obyvatel v daném kraji. Výsledky byly vizualizovány prostřednictvím komparativních mentálních map jak gouldovského, tak i lynchovského typu. ${ }^{23}$

První oblast, která se zmíněnými nástroji zkoumala, se dotýkala fenoménu česko-německé jazykové hranice, respektive tzv. Sudet a představ dotazovaných o rozsahu této oblasti. ${ }^{24}$ Pro tyto potřeby byli účastníci výzkumného šetření konfrontováni s mapou severozápadních a přilehlé části středních Čech, do níž zakreslovali průběh této hranice před druhou světovou válkou. Takto získaná data měla již primárně prostorový charakter (lynchovský typ mentální mapy).

Představy respondentů o dané hranici byly velmi rozmanité, v některých prrípadech se lišily o více než $120 \mathrm{~km}$. Ve třech případech dotazovaní uvedli, že hranice "Sudet“ je totožná se současnou státní hranicí. Opačným extrémem byli respondenti, kteří zakreslili linii hluboko do českého vnitrozemí a dle jejichž mínění patřila do této oblasti např́ílad

${ }^{23}$ Metodu mentálního mapování vypracovali jako první nezávisle na sobě Kevin Lynch a Peter Gould spolu s Rodneyem Whitem. Podle rozdílného př́stupu těchto autorů rozlišujeme tzv. gouldovský a lynchovský typ mentálních map. $\mathrm{V}$ gouldovském pojetí mentálních map se sledují kladné či záporné preference respondentů ve vztahu k určitým lokalitám a samotná mentální mapa vzniká až následným kartografickým zpracováním získaných informací. V lynchovském pojetí je mapa naopak tvořena př́mo samotnými respondenty, kteří tak vyobrazují vlastní vnímání prostoru. Z hlediska tvorby mentálních map jsme během výzkumu využili obou těchto př́stupů. Blíže k oběma konceptům srov. Gould a White [1974], Lynch [1960].

${ }^{24}$ Termínem „Sudety“, pomineme-li původní geografické vymezení tohoto pojmu, se označují oblasti, jež byly před rokem 1945 většinově obývané německy hovořícím obyvatelstvem. Nejasnosti však panují v otázce, o jakou oblast se co do rozsahu jedná: zda se pod toto označení řadí také tzv. jazykové ostrovy ve vnitrozemí, či se jedná o oblasti obsazené po mnichovské konferenci nacistickým Německem. Území, které bylo německou armádou v roce 1938 zabráno, neodpovídalo tehdejší česko-německé jazykové hranici a zahrnovalo také řadu českých obcí. $\mathrm{V}$ dnešním obecném povědomí jsou ovšem tyto linie často vnímány jako shodné. Pro zjednodušení byla $\mathrm{v}$ rámci našeho výzkumného šetření použita tzv. pomnichovská hranice, která je zaznamenána také v Mapě 1. K pojmu „Sudety“ bliže Arburg, Staněk [2010a: 303-304]. 


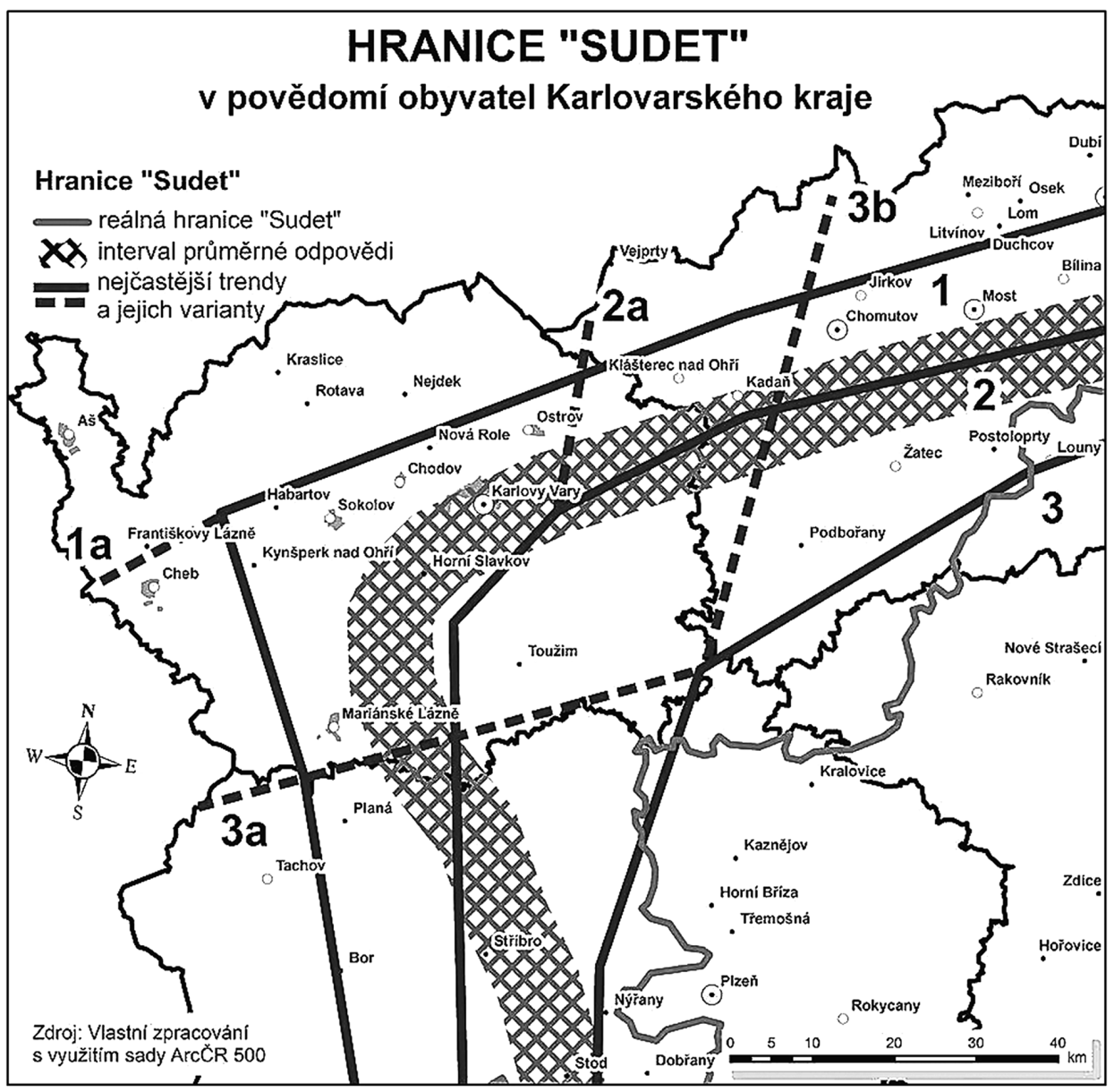

Mapa 1

města Kladno nebo Beroun. Ve výše zobrazené mapě je průměrná hranice zakreslena desetikilometrovým intervalem vypočítaným na základě spojnic trendů, který přibližně kopíruje státní hranici ve vzdálenosti 40 až 50 kilometrů směrem do českého vnitrozemí. Průměrná odpověd' se v oblasti Karlovarského kraje výrazně liší od reálné hranice „Sudet“, jež je v mapě znázorněna světle šedou linií, a to v některých oblastech až o 60 kilometrů. Naproti tomu v oblasti Plzeňska a Lounska přibližně odpovídá realitě.

Nejčastěji se objevovaly tři varianty odpovědí s přibližně stejnou četností, které dohromady reprezentují necelé 4/5 respondentů. První skupina respondentů zařadila do oblasti „Sudet“ pouze pohraniční horská pásma (viz varianta 1 na Mapě 1). Hlavní centra osídlení s výjimkou Chebu a Aše označili jako česká. Velmi často respondenti při zakreslování hranice uvažovali pouze o severní části regionu. $V$ těchto případech linii vyznačili přibližně v ose Cheb-Teplice (varianta 1a na Mapě 1) a průběh hranice v jižní polovině mapy již nevyznačili. Druhá skupina respondentů uvedla hranici přibližně odpovídající intervalu 
průměrné odpovědi (varianta 2 na Mapě 1). Hranice „Sudet“ podle jejich vnímání kopíruje jižní okraj podkrušnohorských pánví a přes Slavkovský les pokračuje směrem k městu Stříbro. V př́padě druhé varianty často respondenti vyznačovali hranici pouze v severojižním směru (varianta 2a na Mapě 1). Třetí varianta nejvíce odpovídá reálné historické hranici „Sudet“. Ta se objevovala u necelé tř̌etiny respondentů. I v této variantě někteří respondenti vnímali hranici jen v západovýchodním či severojižním směru (varianty 3a, 3b na Mapě 1), i když v menší míře než u předchozích variant. Odpovědi ostatních respondentů byly kombinací těchto tří variant nebo se jednalo o zcela specifické a ojedinělé odpovědi.

Prostorové povědomí o skutečnostech souvisejících s česko-německým soužitím v Karlovarském kraji jsme zjištovali rovněž mapami gouldovského typu, v rámci kterých byly prostorově znázorňovány primárně slovní výpovědi respondentů. V šetření měli respondenti uvést obec, kde podle jejich úsudku žije v současnosti největší počet českých občanů německé národnosti. Zároveň byli také požádáni, aby odhadli, kolik procent obyvatelstva této obce Němci tvoří. Výsledky jsou vizualizovány v Mapě 2.

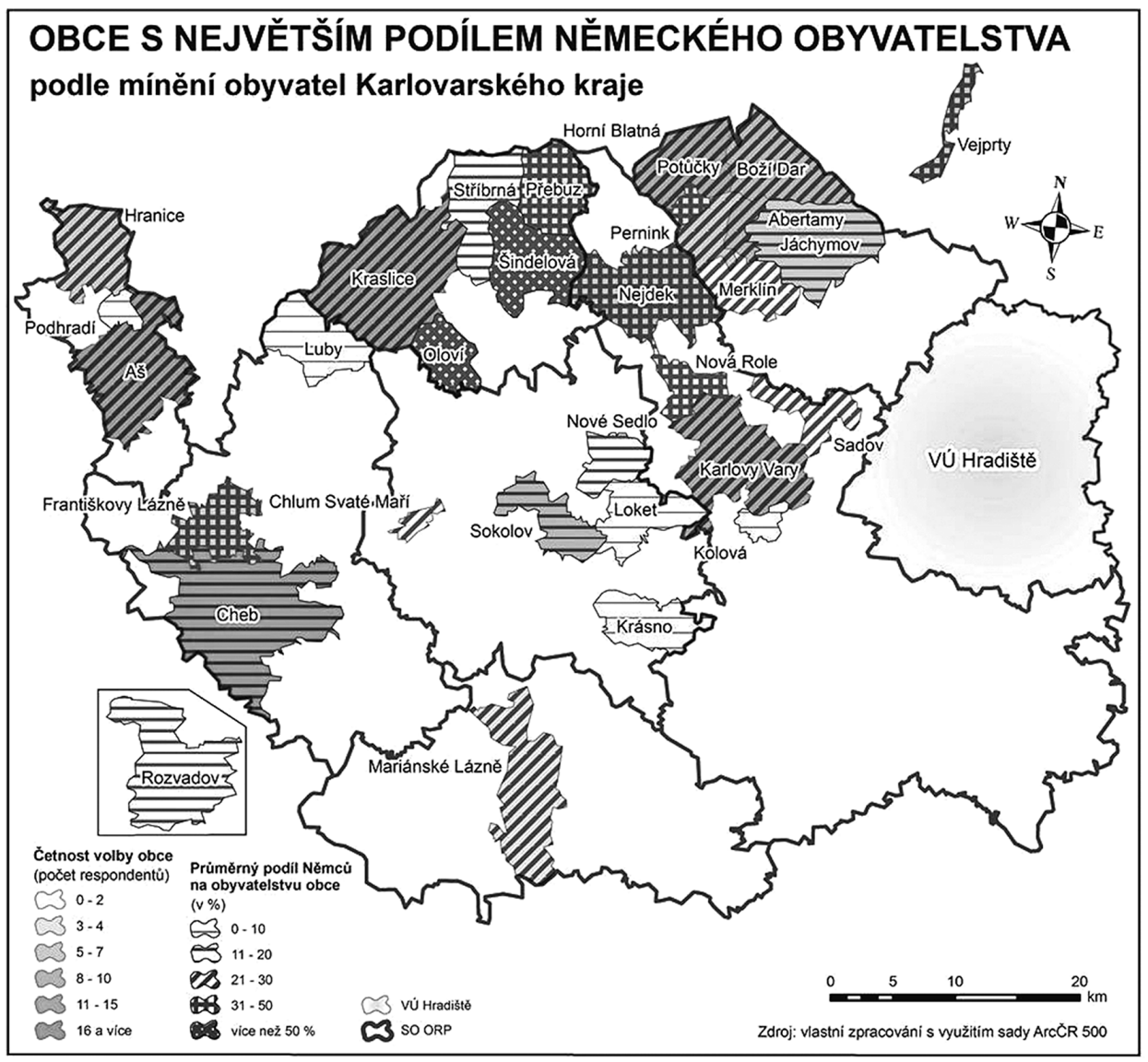

Mapa 2 
Překvapivě nebyla během výzkumu ani jednou zmíněna obec Tatrovice, která v Karlovarském kraji dlouhodobě zaznamenává největší podíl obyvatelstva německé národnosti $(20,90 \%)$ a celorepublikově v tomto ohledu obsazuje hned po Měděnci v Ústeckém kraji druhé místo. Další obce s vysokým podílem osob německého pưvodu, jako například Stříbrná (16,67 \%), Horní Blatná (15,60\%), Abertamy (14,62 \%), Boží Dar (13,53 \%), Pernink $(12,61 \%)$ nebo Krásno (10,43 \%), se sice v odpovědích již objevovaly, nejčastěji však dotazovaní uváděli město Cheb (1,27 \%), dále také Aš (3\%) a Kraslice $(5,17 \%) .{ }^{25}$

Na základě Mapy 2 lze identifikovat pět nejčastěji uváděných oblastí. Regionem, kde podle dotazovaných německá menšina v současnosti dosahuje největšího podílu na obyvatelstvu, je střední Krušnohoří, což odráží názor zhruba 1/5 respondentů. Sem patří například Potůčky, Boží Dar nebo Abertamy. Tuto oblast označili jak samotní respondenti, kteří odtud pocházejí, tak i značná část z Karlovarska. Druhou velmi často uváděnou oblastí byla západní část Krušnohoří v čele s Kraslicemi. Obce z tohoto regionu byly preferovány zejména lidmi pocházejícími z Karlovarska, Salubie ${ }^{26}$ a samotnými občany tohoto regionu. Třetí nejčastěji uváděnou oblast představuje Ašský výběžek, který byl uváděn zejména obyvateli Kraslicka, Karlovarska a Chebska. Celkově se k Ašsku přikláněli respondenti z různých částí kraje poměrně rovnoměrně. Podobně si stojí i čtvrtá oblast - Chebsko. Tu volili jak samotní obyvatelé Chebska a Salubie, tak i obyvatelé Mariánskolázeňska a Karlovarska. Dále se v průzkumu často objevovala města Karlovy Vary a Sokolov. Zatímco Sokolov volili zejména samotní obyvatelé Sokolovska, tak Karlovy Vary uváděli především obyvatelé Chebska. V této souvislosti je jistě zajímavé sledovat, jaké představy mají obyvatelé určitých oblastí o sousedních regionech, respektive městech. Ve vztahu mezi Aší a Chebem nebo Chebem a Karlovými Vary se tak jasně ukazuje vzájemný obraz „toho druhého“ jako města se silnou německou minoritou.

Zcela specifické případy tvořily dvě obce vyznačené respondenty, které se nacházely mimo Karlovarský kraj (Rozvadov a Vejprty). Zatímco Rozvadov dle sčítání lidu v roce 2001 zaznamenává necelé jedno procento občanů německé národnosti, Vejprty s 11,27 \% patří v rámci České republiky $\mathrm{k}$ sídlům $\mathrm{s}$ největším podílem občanů německé národnosti [ČSÚ, Sčitání lidu, domů a bytů]. Prakticky vůbec se v šetření neobjevovaly obce z jihovýchodní části kraje, což odpovídá předchozímu zjištění, dle kterého většina respondentů tuto oblast nezahrnuje do „Sudet“ (viz Mapa 1).

V druhé části této otázky měli dotazovaní procentuálně vyjádřit podíl Němců na obyvatelstvu v obci, kterou uvedli jako s největším početním zastoupením tohoto etnika. Také zde se představy respondentů velmi rozcházely, udávané hodnoty se pohybovaly od jednoho do $85 \%$. V průměru se podíl pohyboval okolo $24 \%$, přičemž mediánovou odpovědí bylo $20 \%$. Nejvyšší uváděný podíl v průměru byl zaznamenán u obcí Šindelová a Oloví, kde podle respondentů tvoří 50, respektive 69 \% obyvatelstva Němci (viz Mapa 2). Tyto obce však byly uvedeny vždy pouze dvěma osobami. Pro úplnost dodejme, že dle sčítání

25 V závorkách je uveden podíl občanů německé národnosti na počtu žijících obyvatel v daných obcích v procentech dle sčítání lidu v roce 2001. Při posledním sčítání lidu v roce 2011 se počet Němců výrazně snížil. Tato data však mohou být značně zkreslena, nebot přibližně třetina obyvatel z každé obce neuvedla svou národnost [ČSÚ, Sčítání lidu, domů a bytů].

26 Salubia je označení pro historickou oblast severozápadního okraje českých zemí, která zahrnuje Luby a okolní obce. 
lidu v roce 2001 se v Šindelové k německé národnosti hlásilo 3,91 \% a v Oloví 8,15 \% [ČSÚ, Sčitání lidu, domů a byti̊].

V rámci výzkumného šetření jsme rovněž zjištovali postoje obyvatel Karlovarského kraje k německé menšině, jejíž početní zastoupení je zde relativně vysoké, jak jsme již poukázali v úvodní části textu. Pracovali jsme proto s předpokladem, že tato skupina obyvatelstva bude ve sledovaném regionu „viditelnější “ nežli v ostatních částech České republiky, což se také potvrdilo. Přibližně $2 / 3$ dotazovaných (66 \%) přišly během svého života $\mathrm{v}$ pohraničí do přímého kontaktu s př́islušníky německé menšiny. Necelá třetina $(30 \%)$ se svými německými sousedy neměla žádnou zkušenost, což lze mimo jiné přičíst vysokému stupni kulturní a jazykové asimilace této skupiny, která činí toto obyvatelstvo na „první pohled“ nerozpoznatelným. Při hodnocení vztahu k německé minoritě vyjádřila více než polovina respondentů (51\%) názor, že zastává stejný vztah k Němcům jako k ostatním menšinám v regionu. Další třetina dotazovaných (32\%) vnímala tuto skupinu obyvatelstva kladněji než ostatní. Pouhých $6 \%$ se v tomto ohledu vyjádřilo negativně. Lze tedy konstatovat, že u respondentů převládá k občanům německé národnosti spíše pozitivní vztah, byt jejich představy o osídlení a působení této skupiny v dané oblasti se od historické reality značně liší.

\section{Závěr}

Současná společnost Karlovarského kraje se začala formovat po konci druhé světové války, v době osidlování pohraničí, které probíhalo souběžně s nuceným vysídlením německy hovořících obyvatel. Jedná se tedy o společnost poměrně mladou, jíž se oproti jiným regionům, nezasaženým poválečným transferem, přisuzuje slabší regionální identita [srov. Zich 2007: 51]. Soudržnost obyvatel a jejich svázanost s teritoriem byla přinejmenším u první generace novoosídlenců nízká, nemluvě o slabě zakořeněných tradicích a zvycích a místním folklóru, který zde prakticky chybí. Každodenní zkušenosti a znalosti někdejších obyvatel, kteří zde po staletí žili a hospodařili, nebyly v poválečné protiněmecké atmosféře až na výjimky žádané a postupně pamět těchto lidí upadla v zapomnění. Navíc se tzv. sudetoněmecká otázka stala předmětem záměrné manipulace a tabuizace ze strany komunistického režimu a zkreslená fakta pronikala do historického vědomí tehdejší společnosti. Po roce 1989 se však otevřel prostor pro objektivnější a kritičtější rozpravu o dějinách česko-německého soužití a je jistě zajímavé sledovat, jaké názory, postoje a povědomí o německé minulosti svého kraje zdejší obyvatelé dnes mají.

Ukazuje se, že aktéři našeho výzkumného šetření se k současné německé menšině Karlovarského kraje staví spíše kladně, a to i navzdory disharmonii v historickém vývoji jejich vzájemných vztahů. Samotná otázka nuceného vysídlení německy hovořících obyvatel včetně konfiskace jejich majetku však dodnes společnost rozděluje a během diskuse se objevují rozličné názory na opodstatněnost a spravedlivost tohoto aktu. Obavy z potenciálních restitučních řízení mohou pocitovat zejména obyvatelé pohraničí, což shodně prokázal také náš výzkum, během něhož byl zvýšený počet zastánců „Benešových dekretư “ zaznamenán převážně u osob, které obývají domy po někdejších německých majitelích.

Přestože Karlovarský kraj patří tradičně k oblastem s nejpočetnějším zastoupením občanů německé národnosti a také organizace německé menšiny zde vystupují výrazněji 
nežli v jiných částech republiky, reálné představy o této skupině a její minulosti spíše absentují. Zatímco lepší orientace panovala v odhadech současného prostorového rozložení Němců v regionu, kdy respondenti jejich největší koncentraci přisuzovali zejména obcím v blízkosti svého bydliště a lze tak předpokládat, že zde vycházeli z vlastní zkušenosti, historické reálie a souvislosti jim byly do velké míry vzdálené. Prokázala se značná diskrepance mezi historickým vědomím dotazovaných a historií. Získaná data ilustrují zkreslené představy jak o počtu osob přináležejících $\mathrm{k}$ německému etniku v minulosti a dnes, době jejich osídlení pohraničí, tak například i o průběhu česko-německé jazykové hranice. Jako významný faktor se v těchto otázkách projevilo generační zasazení respondentů. Zástupci nejstarších ročníků se svou vlastní historickou zkušeností vykazovali přesnější výpovědi nežli mladší dotazovaní, do jejichž historického vědomí se informace o německé minulosti kraje dostávají už jen zprostředkovaně a na mnohé mohou předválečné a poválečné dějiny působit až příliš vzdáleně. Na straně druhé jsou to často právě zástupci mladších generací, kteří diskusi o česko-německém soužití se zájmem otevírají, hledají německé kořeny daného regionu a díky časovému a emocionálnímu odstupu rozmělňují vyhraněné postoje k jinak ožehavým tématům „odsunu“ a „Benešových dekretů“.

\section{Literatura}

Alexander, Jeffrey, Ch. - Eyerman, Ron (ed.) [2004]. Cultural Trauma and Collective Identity. Berkeley: University of California Press.

Arburg, Adrian von - Staněk, Tomáš (ed.) [2010a]. Vysídlení Němců a proměny českého pohraničí 1945-1951: Češi a Němci do roku 1945. Středokluky: SUSA.

Arburg, Adrian von - Staněk, Tomáš (ed.) [2010b]. Vysídlení Němců a proměny českého pohraničí 1945-1951: Akty hromadného násilí v roce 1945 a jejich vyšetrovování. Středokluky: SUSA.

Arburg, Adrian von - Staněk, Tomáš (ed.) [2011]. Vysídlení Němců a proměny českého pohraničí 1945-1951: Akty hromadného násili v roce 1945 a jejich vyšetřování. Stř̌edokluky: SUSA.

Assmann, Aleida [2006]. Der lange Schatten der Vergangenheit: Erinnerungskultur und Geschichtspolitik. München: C. H. Beck.

Assmann, Jan [2001]. Kultura a pamét: Písmo, vzpomínka a politická identita v rozvinutých kulturách starověku. Praha: Prostor.

Blaive, Muriel - Mink, Georges [2003]. Benešovy dekrety: Budoucnost Evropy a vyrovnávání se s minulostí. Praha: CEFRES.

Breakwell, Glynis [1993]. Social representations and social identity. Papers on social representations 2 (3): 198-217.

Centrum pro výzkum veřejného mínění (CVVM) Sociologického ústavu AV ČR [online]. Dostupné z: $<$ http://cvvm.soc.cas.cz/mezinarodni-vztahy $>$ [cit. 11. 7. 2016].

ČSÚ. Sčítání lidu, domů a bytů [online]. Dostupné z: < https://www.czso.cz/csu/czso/scitani-lidu-domu -a-bytu> [cit. 11. 7. 2016].

Domnitz, Christian [2007]. Zápas o Benešovy dekrety před vstupem do Evropské unie: Diskuze v Evropském parlamentu a v Poslanecké sněmovně Parlamentu ČR v letech 2002-2003. Praha: Dokořán.

Dvořák, Tomáš [2012]. Vnitřní odsun 1947-1953: Závěrečná fáze „očisty pohraniči“" v politických a společenských souvislostech poválečného Československa. Brno: Matice moravská.

Erll, Astrid [2005]. Kollektives Gedächtnis und Erinnerungskulturen: Eine Einführung. Stuttgart: J. B. Metzler.

Giesen, Bernhard [2002]. Triumph and Trauma. Cambridge: Routledge.

Gould, Peter - White, Rodney [1974]. Mental Maps. Harmondsworth: Penguin.

Halbwachs, Maurice [1994 (1925)]. Les cadres sociaux de la mémoire. Paris: Albin Michel.

Houžvička, Václav [2005]. Návraty sudetské otázky. Praha: Karolinum. 
Houžvička, Václav - Novotný, Lukáš (ed.) [2007]. Otisky historie v regionálních identitách obyvatel pohraničí: Sebedefinice a vzájemné vnímání Čechů a Němců v př́mém sousedství. Praha: Sociologický ústav AV ČR.

Chromý, Pavel - Janů, Helena [2003]. Regional identity, activation of territorial communities and the potential of the development of peripheral regions. Acta Universitatis Carolinae. Geographica 38 (1): $105-117$.

Jeřábek, Milan (ed.) [2012]. Česko-saské pohraničí prostor konkurence a/nebo kooperace? Ústí nad Labem: Univerzita J. E. Purkyně v Ústí nad Labem.

Kreisslová, Sandra [2016]. „Odsun“ Němců v české vzpomínkové kultuře. Národopisná revue 26 (4): 284-295.

Kreisslová, Sandra - Novotný, Lukáš [2015]. Kulturní život německé menšiny v České republice. Praha: Univerzita Karlova v Praze, Právnická fakulta.

Lozoviuk, Petr [2012]. Grenzland als Lebenswelt: Grenzkonstruktionen, Grenzwahrnehmungen und Grenzdiskurse in sächsisch-tschechischer Perspektive. Leipzig: Leipziger Universitätsverlag.

Lozoviuk, Petr (ed.) [2009]. Grenzgebiet als Forschungsfeld: Aspekte der ethnographischen und kulturhistorischen Erforschung des Grenzlandes. Leipzig: Leipziger Universitätsverlag.

Lynch, Kevin [1960]. The Image of the City. Cambridge: MIT Press.

Maslowski, Nikolas - Šubrt, Jiří [2015]. Kolektivní pamět: K teoretickým otázkám. Praha: Karolinum.

Nora, Pierre (ed.) [1984]. Les lieux de mémoire. I - La République. Paris: Gallimard.

Nosková, Jana - Čermáková, Jana [2013]. „Měla jsem moc krásné dětstvi“": Vzpominky německých obyvatel Brna na dětství a mládí ve 20.-40. letech 20. století / „Ich hatte eine sehr schöne Kindheit": Erinnerungen von Brünner Deutschen an ihre Kindheit und Jugend in den 1920er-1940er Jahren. Brno: Etnologický ústav AV ČR.

Paasi, Anssi [1986]. The institutionalization of regions: A theoretical framework for understanding the emergence of regions and the constitution of regional identity. Fennia 164 (1): 105-146.

Rak, Jiří [1994]. Bývali Čechové... České historické mýty a stereotypy. Jinočany: H\&H.

Spurný, Matěj [2011]. Nejsou jako my: Česká společnost a menšiny v pohraničí (1945-1960). Praha: Antikomplex.

Staněk, Tomáš [1991]. Odsun Němců z Československa 1945-1947. Praha: Academia.

Staněk, Tomáś [1993]. Německá menšina v českých zemích 1948-1989. Praha: Institut pro středoevropskou kulturu a politiku.

Staněk, Tomáš [1996]. Perzekuce 1945: Perzekuce tzv. státně nespolehlivého obyvatelstva v českých zemích (mimo tábory a věznice) v květnu-srpnu 1945. Praha: Institut pro středoevropskou kulturu a politiku.

Staněk, Tomáš [2005]. Poválečné "excesy" v českých zemích v roce 1945 a jejich vyšstřování. Praha: Ústav pro soudobé dějiny AV ČR.

Statistický lexikon obcí v republice československé [1934]. Praha: Orbis.

Šmídová, Olga [1998]. Česko-německé vztahy v zrcadle tisku. In. Křen, Jan - Brokolová, Eva (ed.). Obraz Němců a Rakouska a Německa v české společnosti 19. a 20. století. Praha: Karolinum, s. 268-280.

Šubrt, Jiří (ed.) [2010]. Historické vědomí jako předmět badatelského zájmu: Teorie a výzkum. Kolín: Nezávislé centrum pro studium politiky.

Šubrt, Jiří - Pfeiferová, Štěpánka [2010]. Nástin teoreticko-sociologického př́stupu k otázce historického vědomí. In. Šubrt, Jiří (ed.). Historické vědomí jako predmět badatelského zájmu: Teorie a výzkum. Kolín: Nezávislé centrum pro studium politiky, s. 21-30.

Šubrt, Jiří - Vinopal, Jiří, a kol. [2012]. Historické vědomí obyvatel České republiky perspektivou sociologického výzkumu. Praha: Karolinum.

Tomášek, Marcel [2015]. Různá nahlížení na kolektivní pamět: Koncept sociálního traumatu jako jeden z aktuálních přístupů. In. Maslowski, Nikolas - Šubrt, Jiří (ed.). Kolektivní pamět: K teoretickým otázkám. Praha: Karolinum, s. 179-194.

Welzer, Harald [2002]. Das kommunikative Gedächtnis: Eine Theorie der Erinnerung. München: Beck.

Zich, František [2007a]. Přeshraniční vlivy v českém pohraničí. Ústí nad Labem: Univerzita J. E. Purkyně v Ústí nad Labem.

Zich, František [2007b]. Regionální identita obyvatel českého západního pohraničí. In. Houžvička, Václav - Novotný, Lukáš (ed.). Otisky historie v regionálních identitách obyvatel pohraničí: Sebedefinice a vzájemné vnímání Čechů a Němců v př́mém sousedství. Praha: Sociologický ústav AV ČR, s. 49-64. 
Zich, František - Roubal, Ondřej - Spalová, Barbora [2007]. Mezigenerační biografická konfigurace obyvatel české ćásti Euroregionu Nisa. Praha: Sociologický ústav AV ČR.

Zmizelé Sudety / Das verschwundene Sudetenland [2003]. Domažlice: Antikomplex.

Sandra Kreisslová $\left({ }^{*} 1981\right)$ absolvovala doktorské studium na Ústavu etnologie Filozofické fakulty Univerzity Karlovy a již dlouhodobě pưsobí jako odborná asistentka na Provozně ekonomické fakultě České zemědělské univerzity v Praze. Odborně se zabývá výzkumem identitárních a vzpominkových konstrukcí v prostoru česko-německé a česko-rakouské hranice.

Václav Jaroš $\left({ }^{*} 1986\right)$ piơsobí jako interní doktorand na katedře Sociální geografie a regionálního rozvoje Prírodovědecké fakulty Univerzity Karlovy. V rámci své odborné činnosti pưsobí na zminèné katedře jako člen Výzkumného centra dopravní geografie (CeDoG) a Centra pro výzkum v kulturní a historické geografii (KUHIG). 